\title{
IMPLEMENTASI KEBIJAKAN MATA KULIAH PENDIDIKAN KEWARGANEGARAAN SEBAGAI PENDIDIKAN KARAKTER DI PERGURUAN TINGGI
}

\author{
Rinita Rosalinda Dewi ${ }^{1}$, Edi Suresman ${ }^{2}$, Lidya Mustikasari ${ }^{3}$ \\ Universitas Pendidikan Indonesia ${ }^{1,2}$, STIT Qurrota A'yun Samarang Garut ${ }^{3}$ \\ rinitarosalindadewi@upi.edu, esuresman@yahoo.com, \\ mustikasari.lidya@gmail.com
}

\begin{abstract}
ABSTRAK
Perguruan Tinggi merupakan salah satu jenjang pendidikan yang menghadapi permasalahan pada abad 21 yaitu meningkatnya kasus tawuran antar pelajar dan mahasiswa, mabuk-mabukan, narkoba, kasus pemerasan hingga kekerasan diantara pelajar dan mahasiswa, tingginya tingkat kepercayaan dosen kepada mahasiswa untuk bisa mengurus dirinya sendiri yang seringkali disalahgunakan serta plagiasi karya ilmiah. Penelitian ini bertujuan untuk membangun insan berkarakter dan bermartabat yakni dapat mengintegrasikan pendidikan karakter melalui mata kuliah Pendidikan Kewarganegaraan (PKn) sebagai mata kuliah wajib umum di perguruan tinggi. STIT Qurrota A'yun adalah salah satu perguruan tinggi yang berusaha membangun kampus yang religius, berkarakter dan bermartabat. Salah satu strategi yang dilakukan oleh STIT Qurrota A'yun adalah dengan kebijakan Pendidikan Kewarganegaraan (PKn) sebagai pendidikan karakter di perguruan tinggi. Penelitian ini menggunakan metode kualitatif deskrptif dan menggunakan teknik pengumpulan data melalui observasi, wawancara, dan studi dokumentasi. Hasil Penelitian menunjukan bahwa pengintegrasian PKn sebagai pendidikan karakter di perguruan tinggi dilakukan dengan memasukkan nilai-nilai karakter seperti religius, semangat kebangsaan, mandiri, dan bersahabat/komunikatif dalam perencanaan (silabus dan RPP), bahan ajar dan media, implementasi di kelas, penilaian, monitoring, dan evaluasi kegiatan secara keseluruhan.
\end{abstract}

\section{Kata kunci: Pendidikan Kewarganegaraan, Pendidikan Karakter, Perguruan Tinggi}

\section{ABSTRACT}

Higher Education is one of the levels of education that faces problems in the $21^{\text {st }}$ century, namely increased cases of brawls between students and university students, drinking, drugs, cases of extortion to violence between students and university students, the high level of lecturer trust in students to be able to take care of themselves, that is often misused and plagiarism of scientific work. This research aims to build character and dignified human beings that can integrate character education through Civic Education as a general compulsory subject in higher education. STIT Qurrota A'yun is one of the tertiary institutions that strive to build a religious, character and dignified campus. One of the strategies carried out by STIT Qurrota A'yun is with the Citizenship Education ( $P K n)$ policy as character education

Jurnal Edueksos Vol. IX, No. 1, Juni 2020

The journal of social and economics education 
in tertiary institutions. This study uses descriptive qualitative methods and uses data collection techniques through observation, interviews, and documentation studies. The results showed that the integration of Civics education as the character in these tertiary institutions can be done by incorporating character values such as religious, national spirit, independent, and friendly/communicative in planning (syllabus and lesson plans), teaching materials and media, implementation in class, assessment, monitoring, and evaluation of overall activities.

\section{Keywords: Civic Education, Character Education, Higher Education}

\section{A. PENDAHULUAN}

Abad ke-21 ditandai sebagai abad keterbukaan atau abad globalisasi (Wijaya, Sudjimat, \& Nyoto, 2016: 263) artinya kehidupan manusia pada abad ke-21 mengalami perubahan-perubahan yang fundamental dan berbeda dengan tata kehidupan dalam abad sebelumnya. Memasuki abad 21 teknologi telah berkembang kian pesat hingga menyentuh berbagai lini kehidupan, tidak terkecuali bidang pendidikan. Rohman, \& Zahri (2018) mengatakan bahwa pendidikan abad 21 sangat penting karena menuntut mahasiswa memiliki keterampilan belajar dan berinovasi, keterampilan menggunakan teknologi dan media informasi, agent of change, serta dapat bekerja dan bertahan untuk menggunakan keterampilan hidup (life skill). Pendidikan di abad 21 dapat dikategorikan menjadi formal, non formal dan informal.

Pendidikan formal atau disebut pendidikan persekolahan adalah jalur pendidikan yang terstruktur dan berjenjang yang terdiri atas pendidikan dasar, pendidikan menengah, dan pendidikan tinggi. Sedangkan pendidikan nonformal adalah jalur pendidikan di luar pendidikan formal yang dapat dilaksanakan secara terstruktur dan berjenjang, dan dan Pendidikan informal adalah jalur pendidikan keluarga dan lingkungan (Depdiknas, 2003). Apabila seseorang telah menyelesaikan pendidikan dasar, pertama, menengah, maka ia dapat melanjutkan kembali pendidikannya pada jenjang pendidikan tinggi (Perguruan Tinggi). Pendidikan Tinggi adalah jenjang pendidikan setelah pendidikan menengah yang mencakup program diploma, program sarjana, program magister, program doktor, dan program profesi, serta program spesialis, yang diselenggarakan oleh perguruan tinggi berdasarkan kebudayaan bangsa Indonesia (Ristekdikti, 2016). 
Selain itu, perguruan tinggi adalah satuan pendidikan penyelenggara pendidikan tinggi yang berkewajiban untuk ikut andil dalam pembentukan karakter bangsa. (Dhiu \& Bate, 2017; Waldrop, dkk, 2018). Dalam penyelenggaran perguruan tinggi tentu saja tidak selalu berjalan mulus, tetapi ada saja berbagai tantangan yang harus dihadapi. Menurut Nasir (dalam Awaliyah \& Maharani, 2018) dikatakan bahwa tantangan yang harus di hadapi oleh perguruan tinggi adalah daya saing, kualifikasi dan kompetensi dosen, peningkatan infrastruktur pendidikan, technology readiness dan lain sebagainya. Selain hadirnya tantangan, muncul pula berbagai permasalahan diantaranya meningkatnya kasus tawuran antar pelajar dan mahasiswa, mabuk-mabukan, narkoba, kasus pemerasan hingga kekerasan diantara pelajar dan mahasiswa, tingginya tingkat kepercayaan dosen kepada mahasiswa untuk bisa mengurus dirinya sendiri yang seringkali disalahgunakan serta plagiasi karya ilmiah (Mansir, 2017: 11).

Melihat hal tersebut tentunya peristiwa ini merendahkan harkat dan martabat manusia serta membuktikkan bahwa perlunya penerapan pendidikan karakter di perguruan tinggi (Hasanah, 2013). Pendidikan Karakter adalah proses pemberian tuntunan peserta/anak didik agar menjadi manusia seutuhnya yang berkarakter dalam dimensi hati, pikir, raga, serta rasa dan karsa (Putra, 2017; Dineen, 2018; Bates, 2019; Peterson, 2019; Watson, 2019). Pendidikan karakter ditempatkan sebagai landasan untuk mewujudkan visi pembangunan nasional, yaitu mewujudkan masyarakat berakhlak mulia, bermoral, beretika, berbudaya, dan beradab berdasarkan falsafah Pancasila (Alawiyah, 2012: 89). Nilai-nilai karakter yang diterapkan di perguruan tinggi adalah memilih nilai-nilai inti yang dikembangkan dalam implementasi pendidikan karakter, khususnya pada masingmasing jurusan/program studi (Hasanah, 2013).

Pendidikan karakter dalam implementasinya di perguruan tinggi, bisa diselipkan pada proses perkuliahan, misalnya pada berbagai mata kuliah yang bersentuhan langsung dengan materi-materi keagamaan maupun kependidikan (Alawiyah, 2012). Dengan melalui mata kuliah tersebut diharapkan ada upaya penanaman nilai karakter oleh dosen pengampu, tanpa memandang apapun nama dan jenis mata kuliahnya. Mata kuliah di perguruan tinggi dibagi menjadi 2 yaitu 
mata kuliah pilihan dan mata kuliah wajib umum (MKWU). Mata kuliah pilihan merupakan mata kuliah yang diambil dan disesuaikan dengan program studi/jurusan yang diambil.

Sedangkan MKWU merupakan mata kuliah yang berupaya untuk mengembangkan kesadaran sosial kritis serta kesadaran terhadap etika, ekologi, dan budaya mahasiswa (Alwasilah \& Puncochar, 2016: 8). Menurut Ristekdikti (2016) MKWU di perguruan tinggi terdiri dari 4 mata kuliah yaitu Agama, Pancasila, Pendidikan Kewarganegaraan, dan Bahasa Indonesia. Mata kuliah yang tergabung dalam MKWU merupakan sebagai fundamen yang memberikan landasan spiritual keagamaan, moral, kebangsaan, nasionalisme, dan sosial budaya dalam mengembangkan bidang ilmu dan keahliannya masing-masing (Rahim, 2018: 17). Setiap MKWU juga ikut andil dalam pendidikan serta penanaman karakter terhadap mahasiswa.

Salah satu MKWU yang memberikan penanaman karakter adalah Pendidikan Kewarganegaraan. Pendidikan Kewarganegaraan (PKn) merupakan mata kuliah yang memfokuskan pada pembentukan warga negara yang memahami dan mampu melaksanakan hak serta kewajibannya untuk menjadi warga negara yang berkarakter seperti yang diamanatkan oleh Pancasila dan UUD 1945 (Sofyan \& Sundawa, 2015; Herlina, 2017; Hidayah, Ulfah, \& Suyitno, 2019). Pendapat lain mengatakan bahwa PKn adalah pendidikan yang mengingatkan akan pentingnya nilai-nilai hak dan kewajiban suatu warga negara agar setiap hal yang di kerjakan sesuai dengan tujuan dan cita-cita bangsa dan tidak melenceng dari apa yang di harapkan (Clark, 2016; Knowles, 2017; Liano, 2017; Ngozwana, 2017; Literat, \& Vilenchik, 2018). PKn di perguruan tinggi dapat diakatakan sebagai sumber nilai dan pedoman dalam pengembangan serta penyelenggaraan program studi guna mengantarkan mahasiswa memantapkan kepribadiannya sebagai manusia Indonesia seutuhnya dan memelihara budi pekerti kemanusiaan yang luhur (Herlina, 2017). Tetapi, dalam pelaksanaannya dalam penerapan mata kuliah PKn ini mucul beberapa permasalahan yaitu praktek perkuliahan yang berlangsung saat ini hanyalah sebatas pendidikan yang berorientasi pada pencapaian tujuan kognitif atau 
pengetahuan saja. Sedangkan, afektif merupakan hal yang berkaitan dengan proses pembentukan karakter/ sikap siswa cenderung diabaikan (Herlina, 2017).

Oleh karena itu, perlunya perbaikan dalam perkuliahan PKn untuk mengembangkan karakter mahasiswa mulai dari perencanaan, proses/pelaksanaan, evaluasi, dan kendala yang akan dialami. Telah banyak penelitian mengenai implementasi kebijakan PKn sebagai pendidikan karakter di Perguruan Tinggi (Alawiyah, 2012; Hasanah, 2013; Sofyan \& Sundawa, 2015; Akbal, 2016; Dhiu \& Bate, 2017; Herlina, 2017; Mansir, 2017; Hidayah, Ulfah, \& Suyitno, 2019). Selanjutnya, untuk konsep kebijakan PKn telah ada beberapa penelitian mengenai kebijakan pendidikan kewarganegaraan sebagai pendidikan karakter (Dianti, 2014). Penelitian tersebut telah dilaksanakan pada jenjang menengah ke atas. Pada jenjang yang lebih rendah, telah ada penelitian mengenai kebijakan PKn sebagai pendidikan karakter di tingkat sekolah dasar (Kurniawan, 2013).

Dengan kata lain, tanpa ada kebijakan pengintegrasian pendidikan karakter ke dalam berbagai mata kuliah maka PKn pada hakikatnya harus dapat mengembangkan pendidikan karakter. Terlebih lagi dengan adanya kebijakan pengembangan pendidikan karakter yang terintegrasi, hal ini akan menjadi tantangan untuk menunjukan bahwa PKn adalah ujung tombak yang tajam bagi pendidikan karakter di Perguruan Tinggi.

\section{B. METODE PENELITIAN}

Penelitian ini menggunakan pendekatan kualitatif dengan metode deskriptif analitis yang bertujuan untuk memahami situasi, peristiwa, peran, kelompok, atau interaksi sosial tertentu (Sugiyono, 2012). Rancangan penelitian yang digunakan dalam penelitian ini adalah studi kasus. Para partisipan terdiri dari dosen dan mahasiswa. Peneliti memilih partisipan tersebut berdasarkan pemahaman mereka tentang masalah yang sedang diteliti. Tempat penelitian dilakukan di Sekolah Tinggi Ilmu Tarbiyah Qurrota A’yun (selanjutnya STIT Qurrota A’yun) Samarang, Garut jurusan Pendidikan Guru Madrasah Ibtidaiyah (PGMI). Jenis data yang diungkapkan dalam penelitian ini adalah bersifat narasi dan uraian serta penjelasan data dari partisipan baik berupa lisan maupun data dokumen yang tertulis, perilaku 
partisipan yang diamati di lapangan juga menjadi data dalam pengumpulan hasil penelitian ini.

Pengumpulan data diperoleh melalui observasi, wawancara, dan studi dokumentasi. Untuk analisis data dilakukan melalui data Reduction (reduksi data) yaitu peneliti memasuki setting kampus sebagai tempat penelitian, maka dalam mereduksi data peneliti akan memfokuskan pada perilaku dosen dan mahasiswa saat kegiatan perkuliahan dan cara dosen menanamkan pendidikan karakter kepada mahasiswa; data Display (penyajian data) yaitu peneliti menyajikan data dalam bentuk teks yang bersifat naratif; conclusion drawing/verification (penarikan kesimpulan dan verifikasi) yaitu peneliti mencari pola kebijakan mata kuliah wajib umum (MKWU) sebagai pendidikan karakter di perguruan tinggi yang dituangkan dalam kesimpulan yang tentatif. Penarikan kesimpulan dilakukan berdasarkan pengambilan intisari dari rangkaian kategori hasil observasi dan wawancara.

\section{HASIL DAN PEMBAHASAN}

Berdasarkan grand design pendidikan karakter tahun 2010, diuraikan bahwa pada lingkungan pendidikan terdapat empat pilar yang dapat dijadikan sebagai wadah penanaman nilai-nilai karakter. Di antara keempat wadah tersebut salah satunya adalah melalui kegiatan belajar-mengajar di kelas yang diintegrasikan pada setiap perkuliahan termasuk dalam hal ini yaitu mata kuliah PKn (Herlina, 2017). Setiap mata kuliah yang diberikan pada mahasiswa di kelas diharapkan dapat memberikan dampak pembentukan karakter. Dalam hal ini ada yang disebut dengan dampak instruksional dan dampak pengiring (nurturant effect).

Mata kuliah PKn sesungguhnya merupakan salah satu mata kuliah yang kaya akan nilai-nilai karakter. PKn merupakan salah satu leading sector dari pembelajaran berkarakter. Namun, pada kenyataan saat ini PKn seakan menjadi mata kuliah yang tidak dianggap begitu penting karena hanya sebatas pada kegiatan menghapal materi dan kurang mampu menjalankan fungsinya sebagai leading sector dari pendidikan karakter. Listyarti (2012: 5-8) mengatakan terdapat 18 nilai karakter bangsa yang harus disisipkan dalam pendidikan yaitu religius, jujur, toleransi, disiplin, kerja keras, kreatif, mandiri, demokratis, rasa ingin tahu, semangat kebangsaan, cinta tanah air, menghargai prestasi, bersahabat/komunikatif, 
cinta damai, gemar membaca, peduli lingkungan, peduli sosial, dan tanggung jawab. Oleh karena itu, peneliti melakukan serangkaian kegiatan agar mata kuliah PKn mampu memberikan pendidikan karakter kepada mahasiswa khususnya karakter religius, semangat kebangsaan, mandiri, dan bersahabat/komunikatif.

Pada tahap perencanaan implementasi kebijakan mata kuliah Pendidikan Kewarganegaraan sebagai pendidikan karakter di perguruan tinggi, yang harus dilakukan adalah mempersiapkan silabus dan Rencana Pembelajaran Semester (RPS). Peneliti melakukan analisis terhadap silabus dan RPS yang dipersiapkan oleh dosen dalam mendukung mata kuliah PKn berkarakter di kelas. Perencanaan pada pembelajaran yang dituangkan pada RPS memiliki fungsi yang besar dalam menyukseskan pendidikan karakter dalam perkuliahan. Hal ini didukung oleh pendapat yang dikemukakan oleh Mulyasa dalam Dianti (2014) yang menguraikan bahwa sedikitnya terdapat dua fungsi RPS dalam menyukseskan pendidikan karakter di sekolah, yaitu:

1. Fungsi perencanaan

Dalam implementasi pendidikan karakter di sekolah (perguruan tinggi), RPP berfungsi untuk mendorong setiap dosen agar lebih siap dalam melakukan kegiatan pembelajaran, membentuk kompetensi, dan karakter peserta didik dengan perencanaan yang matang.

2. Fungsi proses/pelaksanaan.

Untuk menyukseskan implementasi pendidikan karakter di sekolah (perguruan tinggi) RPP harus disusun secara sistematik dan sistematis, utuh dan menyeluruh, dengan beberapa kemungkinan penyesuaian dalam situasi pembelajaran yang aktual. Dalam hal ini, materi standar yang dikembangkan dan dijadikan bahan kajian harus disesuaikan dengan kondisi dan kebutuhan lingkungan, sekolah (perguruan tinggi), dan daerah.

Berikutnya peneliti juga melakukan pengumpulan data dokumentasi berupa silabus dan RPS yang dipersiapkan oleh dosen PKn. Berdasarkan silabus dan RPS yang peneliti dapatkan dari dosen, peneliti melihat bahwa dosen sudah melakukan modifikasi pada beberapa komponen dalam pembuatan silabus dan RPS. Pada pembuatan silabus dan RPS dosen telah melakukan modifikasi dengan 
menambahkan langsung jenis karakter yang ingin dicapai setelah kegiatan perkuliahan seperti karakter religius, semangat kebangsaan, mandiri, dan bersahabat/komunikatif. Hal lain yang dapat dilihat dari silabus berkarakter yang dipersiapkan, bahwa dosen belum begitu melakukan modifikasi dalam komponen teknik penilaian karena pada silabus tersebut serta tidak ada penambahan/modifikasi pada komponen teknik penilaian. Untuk komponen ini dosen sudah mencoba untuk memilih bentuk penilaian tes tertulis dan pengamatan terhadap sikap mahasiswa. Namun, bentuk penilaian tertulis yang diberikan oleh dosen hanya sebatas latihan soal yang menurut peneliti hanya mampu melihat kemampuan kognitif mahasiswa, sedangkan untuk pengamatan sikap dosen hanya melakukan sendiri dan kurang melibatkan peran aktif mahasiswa. Misalnya dengan mengajak mahasiswa melakukan penilaian terhadap diri sendiri atau bisa juga menggunakan bentuk penilaian antar teman.

Maka dari itu peneliti merasa bahwa dosen masih kurang maksimal dalam melakukan modifikasi silabus pada komponen kegiatan pembelajaran dan teknik penilaiannya. Seharusnya dosen lebih melakukan perubahan dan kreatifitas pada tahap tersebut karena kedua komponen tersebut merupakan bagian penting yang harus dimodifikasi agar mendukung perkuliahan berkarakter. Hal ini sesuai dengan pedoman pengembangan silabus berkarakter Depdiknas yang dikutip dalam Gunawan dalam Dianti (2014) bahwa untuk memfasilitasi terjadinya pembelajaran yang membantu peserta didik mengembangkan karakter perlu dilakukan:

1. Penambahan dan/atau modifikasi kegiatan pembelajaran sehingga memuat kegiatan pembelajaran yang mampu mengembangkan nilai-nilai karakter yang diinginkan.

2. Penambahan dan/atau modifikasi teknik penilaian sehingga ada teknik penilaian yang dapat mengembangkan dan/atau mengukur perkembangan karakter.

Berikutnya analisis dokumentasi pada RPS, peneliti juga mengamati komponen-komponen lain, seperti pemilihan metode, kegiatan pembelajaran, media, sumber belajar, dan evaluasi pembelajaran. Pada setiap RPS peneliti melihat bahwa pada setiap pertemuan dosen sudah merencanakan untuk menggunakan beragam sumber media dan metode pembelajaran. Pada setiap pertemuan dosen 
menggunakan beragam sumber belajar seperti buku-buku diktat PKn, internet, informasi/berita dari berbagai media baik cetak ataupun elektronik, dan juga menggunakan sumber belajar langsung, yaitu mahasiswa yang diarahkan untuk belajar langsung dari lingkungan. Kemudian, dosen juga menggunakan beragam media pembelajaran untuk mendukung berhasilnya pengembangan karakter mahasiswa. Media yang rencananya akan digunakan oleh dosen adalah power point/ slide sebagai sarana dosen untuk menjelaskan materi, selanjutnya dosen akan menampilkan berbagai video, film-film pendek, gambar, serta media internet untuk membantu mahasiswa memperdalam informasi yang berkaitan dengan materi yang sedang dipelajari.

Selanjutnya berkaitan dengan metode pembelajaran, sama halnya dengan media dan sumber belajar. Dosen juga telah merencanakan beragam metode pembelajaran dalam mendukung keberhasilan pengembangan karakter mahasiswa. Metode yang digunakan adalah ceramah, tanya jawab, diskusi kelompok, problem solving atau pemecahan masalah, menonton video/film, observasi langsung ke lapangan, dan inkuiri. Berbagai metode yang direncanakan oleh dosen tersebut diharapkan dapat membantu mengembangkan karakter mahasiswa. Secara tidak langsung karakter-karakter yang ingin dikembangkan dapat diintegrasikan pada metode-metode pembelajaran yang digunakan. Penggunaan metode yang beragam diharapkan mampu meningkatkan keaktifan dan kreativitas mahasiswa serta mendukung keberhasilan pengembangan karakternya.

Tetapi, walaupun pada komponen media, metode, sumber belajar dosen telah merencanakan dengan baik, tetapi pada komponen evaluasi atau penilaiannya peneliti melihat bahwa dosen belum merencanakan teknik penilaian yang beragam. Pada RPS, dosen hanya merencanakan bentuk penilaian tes tertulis dan pengamatan sikap mahasiswa saja. Pada penilaian dengan tes tertulis peneliti mengamati bahwa soal-soal tertulis yang dipersiapkan oleh dosen hanya sebatas pada pengukuran kognitif saja. Sedangkan pengamatan sikap terhadap mahasiswa dilakukan hanya oleh dosen saja dan tidak melibatkan mahasiswa, seperti penilaian diri yang dilakukan oleh mahasiswa dan penilaian antar teman. Penilaian yang dapat membantu mengukur perkembangan karakter mahasiswa tersebut di antaranya 
adalah melalui observasi/pengamatan sikap mahasiswa selama proses atau setelah pembelajaran baik yang dilakukan oleh dosen ataupun juga melibatkan mahasiswa melalui penilaian diri atau penilaian antarteman. Selanjutnya bentuk penilaian juga bisa berupa anecdotal record, skala bertingkat, wawancara terhadap mahasiswa, dan portofolio.

Kemudian, berdasarkan data dari observasi dan hasil wawancara, peneliti mengamati bahwa pada langkah-langkah pembelajaran PKn yang dilakukan, dosen telah berupaya untuk mengintegrasikan nilai-nilai karakter yang hendak dicapai dari kegiatan pembelajaran. Mulai dari tahap pendahuluan, inti, dan penutup. Pada tahap pendahuluan dosen melakukan hal-hal yang mampu menyisipkan nilai-nilai karakter pada setiap tahapnya, seperti dosen mempersiapkan keadaan kelas dan mahasiswa untuk berodo'a sebelum memulai perkuliahan. Nilai karakter religius mencerminkan keberimanan terhadap Tuhan yang Maha Esa yang diwujudkan dalam perilaku melaksanakan ajaran agama yang dianut. Lalu mengabsensi dan menanyakan kabar mahasiswa, melakukan apersepsi dengan menanyakan kepada mahasiswa materi sebelumnya dan mencoba menghubungkan dengan materi sekarang, dan dosen menyampaikan kompetensi dan cakupan materi yang akan dipelajari. Tidak lupa dosen menanamkan karakter semangat kebangsaan dengan cara mengajak para mahasiswa untuk menyanyikan lagu kebangsaan Indonesia Raya atau lagu-lagu nasional lainnya. Dosen juga memberikan keteladanan dengan cara datang tepat waktu saat proses perkuliahan akan dimulai, berpakaian rapi dan sopan saat mengajar di kelas dan juga memperhatikan kebersihan ruang kelas. Keteladanan dosen sangat penting demi efektifitas pendidikan karakter.

Pada tahapan kegiatan inti dosen mencoba menyampaikan materi perkuliahan dengan berusaha melibatkan mahasiswa secara aktif. Inti dari pembelajaran berkarakter adalah mahasiswa dilibatkan untuk lebih banyak terlibat, jadi pembelajaran tidak hanya berpusat kepada dosen melainkan kepada mahasiswa. Pada langkah-langkah pembelajaran di kegiatan inti dosen telah mencoba untuk lebih banyak melibatkan mahasiswa untuk menanamkan karakter mandiri dan kerjasama, misalnya dalam penyampaian materi dosen hanya menyampaikan secara umum saja dan mahasiswa diarahkan untuk menggali informasi secara mendalam 
dari berbagai sumber baik secara mandiri atau berkelompok. Selanjutnya dosen menampilkan berbagai video atau film yang berhubungan dengan materi yang sedang dipelajari untuk menanamkan karakter bersahabat/komunikatif kepada mahasiswa. Pada kegiatan ini, dosen mengarahkan mahasiswa untuk mengamati tayangan video atau film dan diminta memberikan komentarnya serta berdiskusi apabila ada permasalahan secara bersama-sama.

Selanjutnya, tahapan terakhir dalam pembelajaran, yaitu kegiatan penutup. Pada kegiatan penutup seorang dosen juga harus mampu mengintegrasikan nilainilai karakter. Berdasarkan data observasi dan wawancara, dosen telah melakukan kegiatan penutup dengan baik dalam membantu mengembangkan karakter mahasiswa. Setelah itu, berdasarkan data yang peneliti dapatkan melalui observasi langsung kegiatan pembelajaran PKn dan wawancara dari dosen yang bersangkutan serta beberapa orang mahasiswa, peneliti melihat bahwa bentuk evaluasi atau penilaian yang dilakukan dalam pembelajaran PKn belum begitu baik karena ketika pembelajaran di kelas, peneliti melihat bahwa dosen tidak menggunakan teknik penilaian yang beragam. Dosen hanya melakukan penilaian berupa penilaian terhadap tugas mahasiswa dalam bentuk tertulis, lalu dosen melakukan penilaian dengan memberikan pertanyaan langsung kepada mahasiswa di akhir pelajaran yang menurut peneliti hanya sebatas pada pengukuran kognitif saja serta melakukan penilaian terhadap sikap mahasiswa selama proses pembelajaran.

Data yang sama juga peneliti dapatkan dari hasil wawancara dengan beberapa orang mahasiswa, yang menyatakan bahwa dosen hanya melakukan penilaian dalam bentuk tertulis, pemberian pertanyaan langsung secara lisan, dan penilaian ketika pelaksanaan diskusi. Hal tersebut menunjukkan bahwa dosen belum maksimal dalam melakukan evaluasi pembelajaran berkarakter. Hal ini dapat dilihat dari teori berbagai teori penilaian pembelajaran berkarakter, yaitu, melalui observasi, wawancara, anecdotal record, skala bertingkat, penilaian diri, penilaian antar teman, dan juga portofolio.

Pada penelitian ini, peneliti juga mencoba mengamati kendala-kendala yang dihadapi oleh dosen dalam mengintegrasikan konsep pendidikan karakter dalam tahap perencanaan, pelaksanaan, dan evaluasi pembelajaran. Pada tahap 
perencanaan terkadang dosen diminta untuk melengkapi hal-hal yang bersifat administratif sehingga penyusunannya tidak terlalu baik. Selanjutnya pada tahap pelaksanaan kendalanya adalah waktu. Terkadang untuk melakukan bentuk pembelajaran yang ideal dalam mendukung pengembangan karakter mahasiswa dibutuhkan waktu yang lebih banyak. Kemudian permasalahan juga berasal dari luar. Banyaknya contoh-contoh yang tidak baik di luar membuat dosen kesulitan untuk menjelaskan hal-hal baik yang ada kepada mahasiswa.

Dalam mengantisipasi permasalahan pada tahap perencanaan, biasanya dosen mencoba memaksimalkan pada tahap pelaksanaan saja meskipun silabus dan RPS yang disiapkan tidak sempurna. Berikutnya mengatasi permasalahan kurangnya waktu, dosen sebisa mungkin mengedit kegiatan yang ada disesuaikan dengan waktu yang tersedia. Sedangkan untuk permasalahan banyaknya contoh-contoh yang kurang baik di luar membuat dosen harus lebih ekstra memberikan penguatan kepada mahasiswa mengenai nilai-nilai yang baik.

\section{KESIMPULAN}

Perencanaan implementasi kebijakan mata kuliah PKn sebagai pendidikan karakter di perguruan tinggi telah disiapkan didukung silabus dan RPS berkarakter yang telah dimodifikasi dengan menambahkan langsung jenis karakter yang ingin dicapai selama kegiatan perkuliahan seperti karakter religius, semangat kebangsaan, mandiri, dan bersahabat/komunikatif terkecuali pada bagian teknik penilaian. Proses/pelaksanaan implementasi kebijakan mata kuliah PKn sebagai pendidikan karakter di perguruan tinggi yaitu dosen PKn telah menerapkan dan menggunakan berbagai metode, media pembelajaran dan sumber belajar yang beragam serta mengintegrasikan berbagai karakter dalam kegiatan perkuliahan seperti karakter religius ketika berdo'a, karakter semangat kebangsaan ketika menyanyikan lagu wajib nasional dan lagu nasional, karakter mandiri ketika mahasiswa mencari sendiri informasi bahan ajar perkuliahan, dan karakter bersahabat/komunikatif ketika dosen memberikan permasalahan untuk didiskusikan secara bersama-sama. Evaluasi implementasi kebijakan mata kuliah PKn sebagai pendidikan karakter di perguruan tinggi yaitu dosen hanya memberikan tes tertulis untuk mengukur kemampuan kognitif mahasiswa. Sedangkan untuk pengamatan sikap dosen 
melakukannya sendiri tanpa melibatkan mahasiswa. Kendala implementasi kebijakan mata kuliah PKn sebagai pendidikan karakter di perguruan tinggi adalah pada tahap perencanaan terkadang dosen diminta melengkapi hal-hal yang bersifat administratif sehingga penyususnannya tidak terlalu baik; untuk melakukan pembelajaran yang ideal dalam mendukung pengembangan karakter mahasiswa dibutuhkan waktu yang lebih banyak; banyaknya contoh yang tidak baik di luar membuat dosen kesulitan untuk menjelaskan hal-hal baik yang ada kepada mahasiswa

\section{REFERENSI}

Akbal, M. (2016). Pendidikan Kewarganegaraan dalam Pembangunan Karakter Bangsa: Seminar Nasional Fakultas Ilmu Sosial Universitas Negeri Makassar dan Himpunan Sarjana Pendidikan Ilmu-ilmu Sosial Indonesia Grand Clarion Hotel, Makassar, hlm. 485-493.

Alawiyah, F. (2012). Kebijakan dan Pengembangan Pembangunan Karakter melalui Pendidikan di Indonesia: Aspirasi, Vol. 3, No. 1, hlm. 87-101.

Alwasilah, C \& Puncochar, J. 2016. Memberdayakan Pendidikan Tinggi di Indonesia. Bandung. Pustaka Jaya.

Awaliyah, G \& Maharani, E. (2018). Ini Tantangan Perguruan Tinggi menurut Menristekdikti [Online].

Tersedia

di https://www.republika.co.id/berita/pendidikan/duniakampus/18/06/07/p8ctn4335-ini-tantangan-perguruan-tinggi-menurutmenristekdikti. Diakses 16 Oktober 2019.

Bates, A. (2019). Character education and the 'priority of recognition'. Cambridge $\begin{array}{llll}\text { Journal of } & \text { 6ducation, }\end{array}$ https://doi.org/10.1080/0305764X.2019.1590529.

Clark, C. H. (2016). Examining the Relationship Between Civic Education and Partisan Alignment in Young Voters. Theory \& Research in Social Education, 45(2), 218-247. http://dx.doi.org/10.1080/00933104.2016.1250690.

Depdiknas. (2013). UU Sisdiknas edisi terbaru. Bandung: Fokusindo Mandiri.

Dhiu, KD \& Bate, N. 2017. Pentingnya Pendidikan Karakter di Perguruan Tinggi: Kajian Teoritis Praktis: $2^{\text {nd }}$ Annual Proceesding STKIP Citra Bakti Bajawa NTT, hlm. 172-176.

Dianti, P. (2014). Integrasi Pendidikan Karakter dalam Pembelajaran Pendidikan Kewarganegaraan untuk Mengembangkan Karakter Siswa: JPIS, Jurnal Pendidikan Ilmu Sosial, Vol. 23, No. 1, hlm. 58-68. 
Dineen, K. (2018). Kant, emotion and autism: towards an inclusive approach to character education. Ethics and Education, 14(1), 1-14. https://doi.org/10.1080/17449642.2018.1505150.

Hasanah, (2013). Implementasi Nilai-Nilai Karakter Inti di Perguruan Tinggi: Jurnal Pendidikan Karakter, Tahun III, No. 2, hlm. 186-195.

Herlina, N. (2017). Pendidikan Kewarganegaraan dan Pancasila untuk Membangun Karakter Bangsa Indonesia di Universitas PGRI Palembang Provinsi Sumatera Selatan: Prosiding Seminar Nasional 20 Program Pascasarjana Universitas PGRI Palembang, hlm. 125-129.

Hidayah, Y., Ulfah, N., \& Suyitno. (2019). Pendekatan Pembelajaran Mata Kuliah Wajib Umum Pancasila dan Pendidikan Kewarganegaraan di Perguruan Tinggi: Jurnal Pancasila dan Kewarganegaraan, Vol. 4, No. 1, hlm. 22-33.

Knowles, R. T. (2017). Teaching Who You Are: Connecting Teachers' Civic Education Ideology to Instructional Strategies. Theory \& Research in Social Education, 46(1), 68-109. http://dx.doi.org/10.1080/00933104.2017.1356776.

Kurniawan, MI. (2013). Integrasi Pendidikan Karakter ke dalam Pembelajaran Kewarganegaraan di Sekolah Dasar : Jurnal Pemikiran dan Pengembangan SD, Jilid 1, No. 1, hlm. 37-45.

Liano, S. M. (2017). The counterfeit presentment: an early $20^{\text {th }}$ century model of intercollegiate debate as civic education. Argumentation and Advocacy, 53(2), 90-102. http://dx.doi.org/10.1080/00028533.2017.1304983.

Listyarti, R. 2012. Pendidikan Karakter dalam Metode Aktif, Inovatif, \& Kreatif. Jakarta: Esensi.

Literat, I., \& Vilenchik, N. K. (2018). Youth online political expression in nonpolitical spaces: implications for civic education. Learning, Media and Technology, 43(4), 400-417. https://doi.org/10.1080/17439884.2018.1504789.

Mansir, F. (2017). Model Pendidikan Karakter di Perguruan Tinggi Islam. (Disertasi). SPS UIN Syarief Hidayatullah Jakarta.

Ngozwana, N. A. (2017). Civic education in Lesotho: implications for teaching of democratic citizenship. International Journal of Lifelong Education, 36(5), 526-540. http://dx.doi.org/10.1080/02601370.2017.1304460.

Peterson, A. (2019). Character education, the individual and the political. Journal of Moral Education, $\quad 0(0), \quad 1-15$, https://doi.org/10.1080/03057240.2019.1653270.

Putra, P. (2017). Implementasi Pendidikan Karakter dalam Pembelajaran IPA di MIN Pemangkat Kabupaten Sambas Kalimantan Barat: Jurnal Ilmiah PGMI, Vol. 3, No. 1, hlm. 49-61.

Rahim, R. (2018). Urgensi Pembinaan Pendidikan Agama Islam Di Perguruan Tinggi Umum (PTU): Jurnal Pendidikan, Vol. 1, No. 1, hlm. 17-26. 
Ristekdikti. (2016). UU No. 20 Tahun 2012. Jakarta : Sumberdaya Ristekdikti.

Ristekdikti. (2016). Surat Edaran: Bahan ajar mata kuliah wajib umum. Jakarta. Direktorat Jenderal Pembelajaran dan Kemahasiswaan.

Rohman, A., \& Zahri, M. (2018). Menggali Nilai-nilai kemandirian dan Komunikasi Interpersonal Mahasiswa Calon Guru pada Mata Kuliah Keterampilan Abad 21: Seminar Nasional Pendidikan Banjarmasin, ISBN 978-602-6483-63-8, hlm. 256-262.

Sofyan, MS \& Sundawa, D. (2015). Hubungan Mata Kuliah Pendidikan Kewarganegaraan dengan Peningkatan Wawasan Kebangsaan dan Semangat Nasionalisme Mahasiswa: Jurnal Pendidikan Ilmu Sosial, Vol. 24, No. 2, hlm. 185-198.

Sugiyono. (2012). Metode Penelitian Kuantitatif, Kualitatif dan $R \&$ D. Bandung: Alfabeta.

Waldrop, dkk. (2018). Measuring the Engagement of College Students: Administration Format, Structure, and Validity of the Student Engagement Instrument-College. Measurement and Evaluation in Counseling and Development, $\quad$ 52(2), 90-107. https://doi.org/10.1080/07481756.2018.1497429.

Watson, L. (2019). Educating for inquisitiveness: A case against exemplarism for intellectual character Education. Journal Of Moral Education, 48(3), 303315. https://doi.org/10.1080/03057240.2019.1589436.

Wijaya, EY., Sudjimat, DA., \& Nyoto, A. (2016). Transformasi Pendidikan Abad 21 sebagai Tuntutan Pengembangan Sumber Daya Manusia di Era Global: Prosiding Seminar Nasional Pendidikan Matematika, Volume 1 Universitas Kanjuruhan Malang, hlm. 263-278. 